The Eastern Librarian, Volume 23(1), 2012, ISSN: 1021-3643 (Print). Pages: 51-63.

Available Online: http://www.banglajol.info/index.php/EL

\title{
BUWAYHID LIBRARY AND ITS MANAGEMENT: A HISTORICAL ANALYSIS
}

\author{
A.T.M. Shamsuzzoha \\ Department of Islamic History \& Culture, University of Dhaka, Dhaka-1000, Bangladesh. \\ E-mail: babu_416@yahoo.com
}

\begin{abstract}
Like the ancient Mesopotamian, Egyptian and Roman library, Muslim library has been introduced from the early age of Islam in demand of time. In the meantime, the emergence of Hazrat Muhammad (Sm.) had started a new era of knowledge and science in Islam. From the very beginning of Islamic civilization many institutions were established and renowned intellectuals and scholars of different fields were associated with those institutions. They made various worthy researches for the development of Muslim knowledge and sciences, in badly need of many libraries. So after several years when the Muslims came closer to the Persian literature and Greek sciences the Islamic library started its journey in the $7^{\text {th }}$ century. So, for the acquisition of knowledge Muslim library has been initiated from the very beginning of Islamic heritage which was started with the mosque though formally introduced by the Baitul Hikmah, by Abbasid khalifa Al-Mamun (813-833). Gradually by the expansion of Islam it was circulated in various countries of the world. In these process Buwayhid ruler came closer to the Abbasid and taught the process of establishing various royal, private and public library. After the inception of royal library the Buwayhid introduced various important functions such as, collection of books, preservation system, translation, cataloguing, inclusion and clarification of the books. Besides these, recruitment, promotion, management of archives and modern system of budgeting were also salient features of their library management. The present study is an attempt to analyze the nature of the Buwayhid royal, private and public libraries. The study will also cover exclusively its library management and its various administrative functions.
\end{abstract}

DOI: http://dx.doi.org/10.3329/el.v23i1.12120

\section{KEYWORDS}

Buwayhid Library, Library Management, Royal Library, Private Library, Public Library. 


\section{PROLOGUE}

The invention of writing was one of the incidents which played an important role to the evolvement of the human civilization. After the invention of Egyptian Hieroglyphics, superior's Cuneiforms of ancient civilization, human beings contributed a lot with their writings for the acquisition of knowledge and construction of society. In the ancient period, different libraries were established to bring the scientific knowledge closer to the mankind based on different memorials. Since then, library started its journey as one of the best sources of knowledge.

In this regard, Royal library of king Asurbanipal's of Mesopotamia can be mentioned. After the various stages of evolvement, the library achieved novelty during the Roman civilization. It is believed that 28 libraries were founded only in the city of Rome. In 476 B.C, the fall of Western Roman civilization paved the way for the dramatic incidents of the Middle Ages (500-1000 B.C) and which regarded as a "Dark Age" in the history of Europe (Gates, 1968, p. 22). In the meantime, the emergence of Hazrat Muhammad (Sm.) had started a new era of science and knowledge. Muhammad (Sm.) emphasized science and knowledge on priority importance to the Muslim's. Though the Muslims practiced Prophet (Sm.) teachings but they did not have their high moral development. So after several years when the Muslims came closer to Persian literature and Greek sciences the Islamic library started its journey in the $7^{\text {th }}$ century. From the very beginning of Islamic civilization many institutions were established and became renowned intellectuals of different fields were associated with those institutions. The Muslim scholars developed the education system and interpreted and explained the religion of Islam. In this regard, Seyeed Nasr Hossain said, "At the beginning of the Islamic period, lots of schools and institutions based on Muslim language and culture were established which were playing a significant role to the foundation of University. And this example of $10^{\text {th }}$ and $12^{\text {th }}$ century was a landmark for the establishment of the European University (Hossain, 1968, pp. 65-66)." The small version of Muslim library started its informal journey centering on those institutions. During the Umayyad period (661-750 B.C), this trend was gradually increased outside the Arab world. But in the Arab world Abbasid khalifa Al Mamun (813-33) came forward with the establishment of Bitul Hikmah. It is believed that the Muslim private library or public library was, for the first time, established in this period. The Buwayhid Emirate was established

52 The Eastern Librarian-peer-reviewed journal in LIS since 1965 
under Muiz al-Dawlah had its center at Shiraz in Persia. Buwayhid library was established to start researching of knowledge in the center of Shiraz. Afterwards, the welcome from the Abbasids to the Buwayhid in Baghdad led the practice of knowledge and sciences, and thus Buwayhid knowledge and science was evolved. As a result, during the fold of the Abbasid Khilafat, the Buwayhid started the journey of their library. Later on, Buwayhid library and its management system and the influence of Buwayhid library on contemporary library and library administration will be highlighted.

\section{OBJECTIVES OF THE STUDY}

The main objective of the study is to explore the history of the Buwayhid library, its various functions of library management such as, collection of books, preservation system, translation, cataloguing, inclusion and clarification of the books etc. The objective also includes finding out the influences of the Buwayhid library and its library administration to the contemporary and modern library and their library administration of the globe.

\section{SCOPE OF THE STUDY}

This study covers the history of the Buwayhid library, its various functions such as, collection of books, preservation system, translation, cataloguing, inclusion and clarification of the books. Besides this, recruitment, promotion, management of archives and modern system of budgeting of the Buwayhid library administration and its related aspects will also be delineated. In this study, the author of this paper tried to find out the influences of the Buwayhid library and its library management on contemporary and subsequent libraries and library administration systems of Muslim Asia, Africa and the Christian Europe.

\section{LIMITATIONS OF THE STUDY}

This study should not be considered as the comprehensive study of the Buwayhid library and its library management. The author only uses, for this study, the original sources which are available at the Dhaka University library and National Public Library of Bangladesh as well as internet. So many other original sources could not be used in this regard. However, the author tried to make it research worthy and valuable.

53 The Eastern Librarian-peer-reviewed journal in LIS since 1965 


\section{METHODOLOGY OF THE STUDY}

At the inception of the study, a methodology for it was formulated. To ensure quality of the study and compiled documentation, the author followed the methodology of description and elucidation. This study concentrates on the Buwayhid library and its various managerial activities. A good number of original books and sources have been consulted by the author for this study. Some secondary sources e.g. books, journal articles, encyclopedias have been used for the study.

\section{BUWAYHID LIBRARY}

In 945 A.C. Muiz ad-Dawlah (Ahmad Ibn Buwaiya) established the first Shiiah Amiri Sultanate at Shiraz of Southern Persia within the reign of the Sunni Abbasid Khilafat of Baghdad. The Amirs and the nobles attempted to follow the Abbasid Khalifa in terms of their socio-cultural development including education, art and culture. Consequently in between $10^{\text {th }}$ to $12^{\text {th }}$ century, Buwayhid Amirs made Shiraz as the center of their cultural activities which had become undefeatable at that time. Therefore, the culture of Shiraz, like the Abbasids of Baghdad became the opponent of Constantinople, the Fatimid of Egypt and the Umayyads of Spain. And they made Shiraz as the second Baghdad (Mahmud, 1959, p. 118). S.K. Padovar said, "Shiraz had become the second center of Islam and had run the same activities like that of the Baghdad of the East (Padover, 1965, pp. 347-54)." At that time, Buwayhid declared knowledge as universal and education was universally implemented with the support of the Buwayhid rulers, aristocrats and educationists. To establish the full-scale, active role of different institutions, libraries were gradually increased. Quotation taken from Ibnul Athir (1160-1232/33 B.C), Ahmed Salabi goes, "Since the period of Abbasids the practice of knowledge started and was disseminated later on (Shalaby, 1954, p. 105)." Like their successors the Seljuk's, Buwayhids also patronized arts and literature and established some libraries in their state. The royal library of Amir Adud al-Dawlah and the private library of Abul Fazl Ibnul Amid (d.971 A.C.), Ismail Ibn Abbad (936999 A.C.) and the library of Sabur Ibn Adrshir were well known. It is known that some personal and local small libraries had emerged before the Royal library. Many different books were available in those libraries including Arab History, books of Islamic Religion, Greek Science, Muslim laws etc. Various books of poems, grammars, literature, astronomy, astrology, biography, law, philosophy and chemistry were open to all. In fact, there were three types of library. 1. Royal library or government library, 2. Private library and 3. Public library. These three types of Buwayhid libraries are briefly discussed below:

54 The Eastern Librarian-peer-reviewed journal in LIS since 1965 


\section{ROYAL LIBRARY OR GOVERNMENT LIBRARY}

As a great patron of knowledge and science like the Abbasids and the Seljuk's the Buwayhid started a journey of their royal library in Shiraz. Bakhtiyar and Habashi, two sons of the Buwayhid Amir Muiz al Dawlah, were lovers of learning and vied with each other for acquisition of documents. Among the confiscated property of the defeated Habashi was his library at Basra containing 15,000 books of different fields (Miskawayh, 1942, p. 331). The Royal library of Adud al-Dawlah son of Amir Rokun al Dawlah and the library of Sabur Ibn Adrshir were notable. The greatest of the Buwayhid rulers, Adud al-Dawlah (947-982) was a great bibliophile (Imamuddin, 1983, p. 30). He had his library at his capital city of Shiraz, housed in a separate building. This library contained a good number of books on scientific literature, theology, astrology, Muslim law and books of Islamic religion and teachings. He also established a great library at Basra by his courtier for the grammarian (Padover, 1965, p. 354). Of the Persian libraries, perhaps the best were those of Shiraz and Merv. The Shiraz foundation was also built by Buwayhid prince Adud al-Dawlah on his palace grounds. His Royal library was under the charge of a director (wakil), a treasurer (khazin) and a collector (mushrif) all chosen from the trustworthy people of Shiraz (Imamuddin, 1983, p. 30). According to Adam Mez, Raisul Forasin, a cloth maker of Shiraz had shown the library to the famous geographer al Maqdisi (Mez, 1973, p. 173). He left behind its vivid descriptions. The geographer Maqdisi says that, the books were well arranged on shelves with separate cupboards and catalogues subject wise. The library had 360 rooms and lawns, for which it appeared like a galley. Besides a considerable number of books it possessed, the library was spectacular for its fine buildings, furniture and arrangements. The building was surrounded by parks and roofed with domes (Imamuddin, 1983, p. 39). The books were catalogued and the library contained the copies of all the books published at his time. It was decorated by nice carpet and curtains. The library building was surrounded by many water pipe with canal flooded by water (Pinto, 1929, p. 228). The library of Shiraz was not open for all. Only the scholar could use this library. According to S. K. Padover, "Of the Persian libraries, perhaps the best were those of Shiraz and Merv (Padover, 1965, p. 354). The library was intact until the time of al-Harriri (d.1122) who mentioned it in his Maqamat. The name of Adud al-Dawlah was attached with another notable library, built at alNajf, named Haidory library. According to Ahmad Shalabi, still now this library is alive with the shrine of Ali bin Abu Talib at al-Najf (Shalaby, 1954, pp. 97-98). Now this library contains a large number of books on Arabic and

55 The Eastern Librarian-peer-reviewed journal in LIS since 1965 
Persian hand written original works though it has no catalogue. This library also contains a good number of books on scientific literature, theology, astrology, Muslim law and books of Islamic religion and teachings. The library was opened only to distinguish people capable of appreciating it (Kabir, 1964, p. 179).

Sharaf al-Dawlah, son of Adud al-Dawlah, an astronomer, built up a new library of his own at Shiraz in Persia. The Buwayhid library at Basra and Ramhurmuz were also visited by Maqdisi. Readers at both the libraries were given stipends. The collection of Basra was bigger and richer than that of Ramhurmuz. The last Buwayhid Amir Majd al-Dawlah had his library at Rayy which was occupied by Sultan Mahmud in July 1029. Its collection on Mutazilite philosophy was burnt and other fifty loads in number were removed (Imamuddin, 1983, p. 30).

\section{PRIVATE LIBRARY}

Besides the illustrious royal library various public libraries were established in the Buwayhid regime. The Buwayhid Wazirs also had rich collections of books. Ustad Abul Fadl Ibn al-Amid (d.971), the Wazir of Amir Rukn al-Dawlah, had one hundred camels loaded of books under the charge of famous historian Abu Ali Miskawayh. This collection preserved books of various fields of science, literature and philosophy. In 965 A.D. when the Khurasani invaders attacked and destroyed Buwayhid state Abul Fadl was anxious mostly for his library rather than the wealth. When he was informed about the safety position of his library from Ibn Miskawayh, his pleasure was remarkable (Pinto, 1929, p. 218). Sahib Ismail Ibn Abbad (b. A.D. 936, d.995), the wazir of Muiz al-Dawlah and Fakhr al-Dawlah was one of a great patron of library. He was the author of a copious Arabic dictionary called Muhit (comprehensive), still partly preserved, and of a treatise on prosody called the Inqa (satisfaction), of which a fine manuscript, dated A.H. 559 (=A.D. 1164), formerly in the possession of M. Schefer, is now in the Bibliotheque Nationale Paris (Browne, 1928, p. 374). The rich collection of Ibn Abbad contained 400 hundred camels loaded books. He was interested in philosophy, science and techniques, and was generous with scholars. It is said that he provided reader and scholars from 100 to 500 dirhams and a garment, but rarely did he gave 1,000 dirhams (Mez, 1973, p. 95). In $17^{\text {th }}$ century, Hazi Khalifa gave a description of Ibn Abbads library. Quotation taken from Ibn Abbads, Hazi Khalifa described that his (Ibn Abbad) library contain 1, 17,000 books. According to Mehdi Nakosteen, the library was not only open for all but also he provided stipend of 1 thousand dinars to the

56 The Eastern Librarian-peer-reviewed journal in LIS since 1965 
scholars (Nakosteen, 1964, p. 67). This library was catalogued properly in ten big volumes at Rayy, which was destroyed when it fell to Sultan Mahmud's hand in July 1029. Among other important libraries the libraries of Abu Nasr Ibn Adarshir, Wazir of Sultan Baha al-Dawlah (989-1022) were notable. Like Abbasid Khalifa Al-Mamun, he established an academy named Darul Ilm (Khizana-i-Sabur) at Alf of Mansur Street in Baghdad, with his private library. Rare Books on sale were shown to him first as he offered reasonably high price. He collected more than 10,000 books most of which were written by famous scholars. It was established at Karkh in Baghdad in 991-92 and sixty six year later this library was destroyed by the soldiers of Saljuq Sultan Tughral Beg in 1055-56 A. D.. The library cum museum of Muhammad bin al-Husain Baghdadi possessed a good number of rare books and articles on various fields of knowledge. Among the scholars, who had rich collections Sufiyan al-Thawri, Waqidi, Amr Ibn Abu Bakr and Ismail had their private libraries, which contained worthy number of books.

\section{PUBLIC LIBRARY}

Besides the Royal and private libraries many public libraries were established during the Buwayhid period. According to S.K. Padover, every important city in Persia had its library. With the royal and private libraries, there were many public libraries for the book readers (Padover, 1965, pp. 352-53). With the help of the Buwayhid Amirs, nobles and great hearted men these types of libraries were established. Like the modern public library the libraries of Basra, Mosul and of Mashhad of Abu Hanifah contained magnificent collection and were opened for all. Famous Muslim geographer Yaqut collected materials for three years for his dictionary Mu'jam al-Buldin from the libraries of Merv and Khwarizm. These libraries were sustained till in 1220 A.D., from the attack of the great Mongol leader Chengiz Khan, who destroyed and burnt the libraries (Hitti, 1960, pp. 413-14). In Mosul, the poet Ibn Hamdan (d.935) founded a house of learning and stocked it with books on all branches of knowledge. It was open to all scholars, and those who were poor were given paper free (Bury, 1923, p. 291). Another important library opened to the public although private was Dar al-Ilm at Mosul, founded by Abul Qasim Jafar Ibn Muhammad Ibn Hamadan al Mosuli (854-934) a library attached to the madrasah at the tomb of Imam Abu Hanifah. Among these some mosque and madrasah based public library were established during the Buwayhid period lending from the culture of Islamic teachings of the Abbasids, the Fatimids and the Umayyad of Spain (Shamsuzzoha, 2010, pp. 113-118). This type of public library was open for all,

57 The Eastern Librarian-peer-reviewed journal in LIS since 1965 
irrespective of cast, color and races. People of different classes came to these libraries and they had the opportunity to read and collect data from the books and articles. Scholars and students had free access to books and many times they were entertained by the owner of the library by various numbers of amount and prizes (Imamuddin, 1983, p. 32). So, all the public library played the role of harbinger of Muslim knowledge and sciences under the Buwayhid.

\section{LIBRARY MANAGEMENT}

Along with the gradual expansion of Islam when the Buwayhid conquered Baghdad, they came closer to the Abbasids and were taught about the process of establishing various royal, public and private libraries. After the inception of royal library the Buwayhid introduced various important functions such as, collection of books, preservation system, translation, cataloguing, inclusion and clarification of the books. Besides this, recruitment, promotions, management of archives were also the salient features of their library management. The noted administrative system of the Buwayhid library management will be briefly discussed below:

\section{Collection of Books}

From the beginning of the civilization Persia had a great center of learning. For this reason people of Persia were civilized and they kept themselves busy gaining knowledge of various fields of science, literature, theology, philosophy, astrology, astronomy and mysticism. For the process of attaining knowledge they perceived the need of worthy books. For these reasons, under the Buwayhid rule various royal, private and public libraries were established. The owner of the libraries collected books from various states and regions, notably Baghdad, Ispahan, Nishapur, Basra, Shiraz, Merv and Mosul. Among them Adud al-Dawlah, the Amir of the Buwayhid collected books of sciences and knowledge of various field available to his times. According to Mafizullah Kabir, it was Adud aim to collect in it every book up to his time in every branch of knowledge (Kabir, 1964, p. 179). He also collected books from various regional representatives. For collecting various books of different fields, he appointed Mushrif (collector) as an official representative (Padover, 1965, p. 354). Mushrif collected rare and authentic books from various centers of learning within Persia or out of Persia. A good number of books of Sabur's academy were collected from the gift of Sabur himself and many learned persons. By these processes this academy collected 10,400 books (Mackensen, 1939, p. 290). Though, according to historian P.K. Hitti, Sabur's academy

58 The Eastern Librarian-peer-reviewed journal in LIS since 1965 
consisted of 10,000 books (Hitti, 1960, p. 472). Rare and valuable books were collected for the royal, private and public libraries by Amir Adud al-Dawlah, Wazir Abul Fadl Ibn al-Amid, Ismail Ibn Abbad and other owner of the libraries. Rare books on sale were shown to them at first and they gave high price for good books. By this process the Buwayhid collected worthy books for their royal, private and public library.

\section{Preservation of Books}

In similar with the modern library preservation system the library of the Buwayhid had a good system of preserving the books. According to Maqdisi, the great geographer, the library of Adud al-Dawlah consisting of good number of books, were well arranged on shelves with separate cupboards. He also mentioned that, the library of Adud al-Dawlah had 360 rooms and an open space. The library had 360 rooms and lawns, for which it look like a gallery (Al-Maqdisi, 1906, p. 449). Besides a considerable number of books it possessed, the library was spectacular for its fine buildings, furniture and arrangements. The building was surrounded by parks and roofed with domes (Imamuddin, 1983, p. 39). In decorating some of the rooms he imitated Chinese porcelain, in others the walls were inlaid in marble, while the walls were gilded and engraved with paintings. Adud al-Dawlah made many book shelves for preserving his books by cataloguing. Noted European Scholar Von Kremer said, "The books were stored in a long arched hall, with stack rooms on all sides. Against the walls stood book presses, six feet high and three yards wide, made of carved wood, with doors which closed from the top down, each branch of knowledge having separate bookcases and catalogues (Kremer, 1877, pp. 483-84)." He built many stages decorated with various designs for using the shelves. All rooms were illustrated by valuable carpets and curtains (Nakosteen, 1964, p. 70). Many of the books of his library were covered and decorated by animal skins and most of them were locked by key on the shelves. Besides the Buwayhid royal library the private and public library also maintained preservation systems. The Haidory library of Najf was maintained perfectly by its owners. All books of this library were well designed and decorated by many illustrious pictures. They used natural medicine to keep their books away from insects.

\section{Cataloguing, Inclusion and Clarification of the Books}

Like the Abbasids, the Buwayhid introduced modern cataloguing and bibliography system to their library administration. According to al-Maqdisi, 
the royal library of Adud al-Dawlah was a well arranged library. All the books of the library were well arranged on shelves with cupboards and catalogues subject wise. The books were catalogued and the library contained the copies of all the books published at his time (Al-Maqdisi, 1906, p. 449). He maintained individual catalogue for individual subjects. Every branch of knowledge had its own cupboards and catalogues in which the names were registered (Kabir, 1964, 179). Like the modern cataloguing system the Buwayhid maintained author's name, book's name, subject matter of the books, publishing authority etc. to the catalogue. All the books of their library were read by the students and scholars. The library authority maintained the system of inclusion and clarification of the books for themselves. Though in many times the author of the books made some notes by subject wise to clarify their speech and arrangement of books. Quotation taken from Abul Hasan al-Baihaki Ahmad Shalaby goes that, the library of Sahib Ibn Abbad maintained cataloguing system and its list of catalogue were in 10 volumes (Shalaby, 1954, p. 81).

\section{Lending of Books}

Lending of books is one of the chief concerns of modern library administration. In the Buwayhid period, many libraries had free access to the scholars and the students. Even the royal library of Adud al-Dawlah was open for notable scholars of contemporary period. We have some pieces of news that the royal library was used by Maqdisi and Yakuti. According to Mehdi Nakosteen, some private and public libraries were opened for all and many times student got stipends by the library authority, among them the library of Ibn Abbad was notable. Many Buwayhid libraries maintained borrowing system of books and articles to the scholars. Scholars, students and common people could borrow necessary books from the libraries for certain period and they returned it after doing their works (Nakosteen, 1964, pp. 67-70). The library of Ibn Abbad was a library among the notable ones which consists that administrative facilities. The libraries of Mosul, Basra and the library of Mashhad Abu Hanifah contained magnificent collection and were opened for all.

\section{Translation and Archival Activities}

Like the Baitul Hikmah of the Abbasids and Darul Ilm of the Fatimid and the royal library administration of the Umayyad of Spain, translation was a salient feature of the Buwayhid library administration. For acquiring and exploring the door of Muslim knowledge and sciences Buwayhid prince Adud al-Dawlah and 
the owner of the private libraries had a great effort to make translation to the various books mainly based on philosophy, medicine, astrology, theology, literature and mysticism. To fulfill the demand of the Buwayhid scholars every year the owner of the libraries religiously perform these duties. With the translation unit the Buwayhid maintained an archive in their libraries. The dictionary of Shib Ismail b. Abbad was called Muhit (comprehensive), still partly preserved, and of a treatise on prosody called the Inqa (satisfaction), of which a fine manuscript, dated A.H. 559 (=A.D. 1164), formerly in the possession of M. Schefer, is now in the Bibliotheque Nationale Paris is a great instance of archival activity of the Buwayhid (Browne, 1928, p. 374). The library cum museum of Muhammad b. al-Hussain Baghdadi possessed rare books and articles for the interest of museum interest which performed as an archive like the modern archives. Among the letters and books of this library some were of Hazrat Ali, his son Hasan and Hussain and the letters of Prophet Muhammad (Sm.) written to kings and chiefs and the writing of early grammarians and theologians (Imamuddin, 1983, p. 32). Except these, the Buwayhid maintained various globes and maps to their libraries which can be counted as an archival performance to modern concept.

\section{Recruitment of the Librarians and other Staffs}

The Buwayhids recruited librarians and necessary staffs for their libraries. They recruited librarian, assistant librarian, copyists, calligraphist, record men, peon and guards, cleaner and other necessary staffs to their libraries. The greatest library of the Buwayhid ruler Adud al-Dawlah at Shiraz had separate library administration. He recruited Wakil (trustee), Khazin (treasurer) and Mushrif (collector) to his library, all from the chosen trustworthy people of Shiraz (Padover, 1965, p. 354). With the royal library, private and public libraries had a brilliant unit of staffs. Noted historian Ibn Miskawayh was a long term chief librarian of Ibn al-Amid libraries. Famous physician and noted Shiiah religious leader, Ibn Muskiya also performed as a Khazin of Ibn al-Amid library. Famous poet of Isfahan, Abu Muhammad Abdullah was a khazin of Ibn Ahmad Sahib's library for many years. The famous Sabur's academy was directed by a scholastic body, notably Abul Husen Muhammad Ibn Harunul Dabbi, Al Kazi Abu Abdullah al-Husen Ibn Harunul Dabbi, Abu Ahmad Abdus Salam, (d.405 A.H.), Abu Monsur Mohammad Ibn Ali (d.418 A.H.) (Shalaby, 1954, p. 93). Abdus Salam from Basra and Abul Monsur acted as a Khazin of this academy. The recruited Wakil (trustee), Khazin (treasurer), Mushrif (collector) and other staffs of the Buwayhid libraries were honored by handsome amount of money

61 The Eastern Librarian-peer-reviewed journal in LIS since 1965 
and facilities. And for the maintenance of the Buwayhid royal, private and public libraries they made an annual budget and collected money by bestowal from the noble and knowledge loving people.

\section{CONCLUSION}

From the discussion aforementioned, it can be said that the development of intellectuality and the establishment of library was among the greatest achievements of the Buwayhid. In the very beginning, the establishment of the center in Persia emphasizing on the intellectual improvement greatly contributed to the evolvement of education including science, art and culture. The libraries established by the Buwayhid played an indispensable role to spread the practice of knowledge and science. Later on those libraries included collection of books, preservation of books, translation, cataloguing, and inclusion and clarification system of the books. Besides these, recruitment, promotion, management of archives and modern system of budgeting were the salient activities of the Buwayhid library management, which played a significant role to the development of library evolvement from Persia to Arabia. This may be considered as the pioneer, which finally influenced the establishment of the library of Muslim Spain as well as to the Fatimid and their managerial activity. Consequently Buwayhid model of library was followed and enormously increased in Sicily, Corsica, Syria, Algeria and Libya and across the Mediterranean regions and was celebrated in Asia, Africa, and Europe. Therefore, it is undeniably true that from the earlier part of $10^{\text {th }}$ century to the later part of $12^{\text {th }}$ century Arabic speaking Muslims were the torchbearers in the domain of art, culture and civilization. In this regard, their libraries had played a phenomenal role.

\section{REFERENCES}

Al-Maqdisi, (1906). Kitab Ahsan al-Taqasim fi al-Aqalim, De. Goeje (ed.), Leiden: Brill.

Browne, E. G. (1928). A Literary History of Persia, vol. I, Great Britain: Cambridge University Press.

Bury, J. B. (1923). Cambridge Medieval History, vol. IV, New York: The Macmillan Company.

Gates, J. K. (1968). Introduction to Libraryship, New York: Mc Graw Hill Book Company.

Hitti, P.K. (1960). History of the Arabs, London: Macmillan.

62 The Eastern Librarian-peer-reviewed journal in LIS since 1965 
Hossain, S. N. (1968). Science and Civilization in Islam, London: Cambridge University Press.

Imamuddin, S. M. (1983). Arabic Writings and Arab Libraries, London: Ta-Ha Publishers.

Imamuddin, S. M. (1983). Some Leading Muslim Library of the World, Dhaka: Islamic Foundation Bangladesh.

Kabir, M. (1964). The Buwayhid Dynasty of Baghdad, Calcutta: Iran Society.

Kremer, A. V. (1877). Culturgeschichte Des Orients Unter Den Cahlifen, vol. II, Vienna: ISBN 1104304023; ISBN-13 9781104304027.

Mahmud, S. F. (1959). The Story of Islam, London: Oxford University Press.

Mez, A. (1973).The Renaissance Des Islam, Trans by Salahuddin Khuda Bukhsh \& D. S. Margoliouth, The Renaissance of Islam, Patna. Government of Bihar.

Miskawayh, I. (1942) Tajarib al-Umam, vol. II, Cairo: The Institute of Ismaili Studies.

Nakosteen, M. (1964). History of Islamic Origins of Western Education; 800-1350 A.D., USA: University of Colorado.

Olga Pinto, (April, 1929). The Libraries of the Arabs During the time of the Abbasids, Islamic culture, Pakistan.

Padover, S. K. (1965) Muslim Libraries in J.W. Thompson (ed.) The Medieval Library, Hafner, New York: McGraw-Hill.

Shalaby, A. (1954). History of Muslim Education, Pakistan: Dar al Kashshaf .

Shamsuzzoha, A.T.M. (2010). Muslim Spainer Gronthagar O Gronthagar Babosthapona, (Library and Library Management in Muslim Spain), Itihas, Vol. 44, Bangladesh Itihas Porishad Potrika, Dhaka.

Mackensen, R. S. (July 11, 1939). Four Great Libraries of Medieval Baghdad, Library Quarterly, USA: University of Chicago Press. 